\title{
Fiqh Reconsidered: Indigenization and Universalization of Islamic Law in Indonesia
}

\author{
Rüdiger Lohlker | ORCID: 0000-0002-3927-0783 \\ Professor of Islamic Studies, Oriental Institute, University of Vienna, \\ Vienna, Austria \\ ruediger.lohlker@univie.ac.at
}

\begin{abstract}
Developments in the Islamic world outside of the MENA region traditionally receive little scientific attention. Contrary to this trend, this article focuses on current debates on and developments in the methodology of Islamic Law in Indonesia that are intertwined with the larger process referred to as 'indigenization of Islam' in the Southeast Asian country. The pluralistic nature of law in Indonesia leaves room for a rather theoretical and non-juridical discussion of figh and enables a renewed exploration of Islamic Law. While easily perceived as a purely religious endeavor, this process comprises important political, social, and religious components and aims at balancing out religious and legal demands and Indonesian culture. By taking various documents and multiple perspectives on Islamic Law into account, this article illustrates the emergence of a genuinely Indonesian Islam and proves how elements of indigenization, globalization, and universalization characterize the process.
\end{abstract}

\section{Keywords}

Fiqh - Islamic Law - Indonesian Islam - Islam nusantara

\section{Introductory Remark}

Often ignored because of the preoccupation in Europe with the development in the Arab world, Turkey and Iran, the important, paradigmatic case of Islamic law, to be more precise: fiqh, in Indonesia, may help to answer the following questions: to what extent can religious freedom, universal human rights 
and the rule of law be integrated in the legal conceptions of religious traditions? Can religions derive argumentative resources thereof against (renewed) political appropriation? In order to understand Islam nusantara, ${ }^{1}$ Islam in the Indonesian archipelago, as the living process ${ }^{2}$ of adapting to ever-changing circumstances, ${ }^{3}$ and not a mere collection of texts dear to any legal historian, there are some crucial texts that we can consult and that will help to conceptualize this living Indonesian Islam. The most important recent document is called the Gerakan Permuda Ansor Declaration on Humanitarian Islam however, there are other documents to be discussed.

This declaration is based on the idea of a new contemporary ijtiha $\bar{a} d^{4}$ being able to augment the existent (i.e., classical) body of legal opinions, particularly in regard to certain areas in which enormous change has occurred in recent centuries. In the history of Islamic law, ijtihād is understood as the process of this reasoning about "extracting a rule from the subject matter of revelation while following the principles and procedures established in legal theory". ${ }^{5}$ But ijtihād is not understood in Classic Islamic Law as all-encompassing. Wael Hallaq said:

We have already intimated that the province of legal reasoning and interpretation, properly called $i j t i h \bar{a} d$, does not extend over the entire range of the law. Excluded from this province is a group of texts which

1 To give an idea of the discussion see, e.g., Bisri/Taylor, Indonesia's,Big Idea; Azra, The Origins of Islamic Reformism in Southeast Asia; Qomar, Islam Nusantara; Khabibi, Islam Nusantara; Susanto/Karimullah, Islam Nusantara; Arifianto, Islam Nusantara; Hasyim, 'Islam Nusantara' and its Discontents.

2 Thanks to C. Holland Taylor for stressing this point.

3 To mention some contextual elements: For a recent study of the emergence of a new popular and visual culture in Indonesia see Schmidt, Islamic Modernities in Southeast Asia. The impact of these societal changes on the development of figh discussions are still to be discussed. A similar case is the vivid pilgrimage culture in Java that has been regarded as a constant rebuke of Islamic rigidity and exclusivism (see Quinn, Bandit Saints of Java, pp. 51-56) with a very illuminating case of an application or non-application of a legal statement ( fatwa) on the qibla. And for the background of our discussion of developments in figh, esp., in Nahdatul Ulama ( $\mathrm{NU}$ ) circles a book on the debate on post-traditionalism: Rumadi, Islamic Post-Traditionalism in Indonesia.

4 We are using a simplified transcription adopting the quotations to this simplified system.

5 Hallaq, A History of Islamic Legal Theory; see Lohlker, Islamisches Recht, p. 185. 
unambiguously state the legal rules of a number of cases. The certainty (qat') generated by these texts ab initio precludes any need for reinterpretation. Some cases in point are the prohibitions imposed, by textual decree, on adultery, homosexuality, and consumption of grape-wine. Also excluded are those cases subject to consensus, the sanctioning instrument that generates certainty. In all other spheres of the law, ijtihād is not only admissible but is also considered a religious duty incumbent upon those in the community who are learned enough to be capable of performing it; this duty is known as fard kifâya. ${ }^{6}$

Thus, in classical Sunni methodology ijtihād is not regarded as a non-restrictive tool for the development of juridical ideas. In Indonesia, we witnessed the emergence of a claim for a new, non-restrictive $\ddot{j} t i h \bar{a} d$. This new ijtihād is embedded in a view of the process of Islam in Indonesia as "Indigenization of Islam" (pribumisasi Islam) ${ }^{7}$ that is intended to avoid polarization between religion (and law) and Indonesian culture. This is not the place to follow the ramifications of the Islamic and non-Islamic debate on ijtihäd. This analysis stresses the Indonesian dimension of this debate. Any inclusion of the discussion in North Africa, Southwest Asia or South Asia would prevent a thorough understanding of the specificity of the Indonesian debate. Reconceptualizing the web of contemporary Islamic thought and practice has to avoid an inclusion of, e.g., Middle Eastern ideas that would affirm the idea of a domination of Middle Eastern ideas in the Islamic world, a faulty approach, since the Indonesian debate constitutes itself against this domination (cf. below).

\section{Shahab Ahmed}

To put it more systematically and to include a perspective reaching beyond the Malayo-Indonesian archipelago, we may follow Shahab Ahmed's groundbreaking reflections that help to reconceptualize Islam in a context that is nonArabic, but stretching out to Southeast Asia and to all of the Persianate world. ${ }^{8}$ A lengthy quotation may be allowed since the present text is not a linear text cut into several sections to follow the structure of conventional texts. The

6 Hallaq, A History of Islamic Legal Theory; see Lohlker, Islamisches Recht, p. 185 et seq.

7 Cf. Wahid, Pribumisasi Islam; see also Wahid, Islam Kosmopolitan.

8 Ahmed refers to the Balkans to Bengal-complex as an alternative to the Arab Islam dominating the discussion of Islamic history. Southeast Asia is not explicitly part of this complex.

Sometimes Ahmed passingly refers to it. 
structure is an interconnected rhizomatic ${ }^{9}$ web of ideas much more appropriate to a world of ideas stretching beyond the clear-cut boundaries of Islamic disciplines or the idea of well-defined regional systems of thought influencing each other.

Thus, the philosophers' identification of the fundamental importance of self-knowledge resounds fully with the goal of the Sufi project which is to attain to just such a level of cosmic or divine self-knowledge - as is summed up in the famous Hadith that has served as a Sufi motto: 'Whoso knows his self knoweth his Lord [man 'arafa nafsa-hu fa-qad 'arafa rabba-hu].' My point, though, is that this sense of the relationship between self and meaning is not a rarefied conceit confined to closed social circles of Sufis and philosophers, but rather a widespread and normal expression and condition of the human and historical fact and experience of being Muslim down the centuries. We should thus not at all be surprised to find that the seventeenth-century leader of the Khatak tribe of Pashtūns, Khwushhāl Khān Khatak (1613-1689), begins his thoroughly down-to-earth manual for virtuous living entitled Dastārnāmah (Book of the Turban), which he authored in Pashtō, 'as instruction and advice for my children, brothers, friends and lovers', with a chapter entitled 'The First Quality: Self-Knowledge [jān pizhandgalvī]'. This chapter sets forth by immediately citing the Hadith, 'Whoso knows himself knoweth his Lord,' followed by a Pashtō translation and gloss in simple rhyme: 'He who has come to know his self - he has come to know God; He who does not know his self does not know God'. Khwushhāl Khān's opening statement indicates not only the extent to which the philosophical-Sufi amalgam pervades and grounds the paideia of the societies of Muslims of the Balkans-to-Bengal complex, but also how, in consequence thereof, selfknowledge was high on the agenda of Muslims acting as Muslims. The full cognizance of the challenges posed to the Muslim individual by engagement in this exploratory undertaking is straightforwardly presented by the anonymous seventeenth-century author of 'one of the most important single documents in the history of the development of Sufi thought in the Indonesian countries,' a didactic poem in Javanese entitled The Gift Addressed to the Spirit of the Prophet (itself an adaptation and elaboration of the Arabic work of the same title by the Gujarātī author, Muhammad al-Burhānpūrî [d. 1620]), who said in introducing his audience of adepts

9 For a presentation of the rationale of this epistemological approach cf. Lohlker, Islamische Texte. 
to the idea of self-knowledge: 'This is difficult and dangerous, perilous and hard to accept except with guidance. The Prophet of God declares: 'Whosoever knows his self there upon knows his Lord' [...] if you do not know your self you cannot know God.' My point here is trying to emphasize this conceptualization in history by Muslims of being Muslim (that is, of human and historical Islam) as the 'difficult and dangerous' exploration of meaning for the Self - a conceptualization all too often lost in the habitual privileging of prescriptive discourses over explorative discourses of meaning - and thus to emphasize the importance of paying due attention, when thinking about Islam or when using the word Islamic, to the larger significance to societies of Muslims of such explorative selfstatements $[\ldots] \cdot .^{10}$

We will have to emphasize that this quest to acquire self-knowledge is not only part of the Balkans-to-Bengal complex but also essential for Southeast Asia. To understand the changes in Indonesian figh, we will have to do what Ahmed prescribes, leaving the "habitual privileging of prescriptive discourses" and "paying due attention" to non-juridical aspects of the understanding of Muslims and their practices of self-exploration. We have to emphasize that this is a process quite normal to the history of Islam and Islamic law.

Our exploration of Indonesian figh starts with an outline of the characteristics of Islamic law in Indonesia that is often ignored in histories of Islamic law and in histories of law in general. It will move to the profound changes that took place within this variant ${ }^{11}$ of Islam in the twentieth/twenty-first century. The intense conflicts starting in the 199os and confronting political Islam/ Wahhabism/Salafism and Islam nusantara will inform the background of the juridical discussion of the recent developments mentioned above. Islam nusantara and its related concepts framing the concepts of figh is contextualized in this vein in an ongoing confrontation with what is understood in important parts of the Indonesian Islamic communities as Arabism, rooted in Middle Eastern culture, i.e., a confrontation with Islam in the tradition of the Muslim Brotherhood, Wahhabism/Salafism, ${ }^{12}$ and Jihadism. ${ }^{13}$ This conceptualization

\footnotetext{
10 Ahmed, What is Islam?, p. 335.

11 I am referring to the idea of variantology coined by Zielinski (see Lohlker, Variantologie des Universellen).

12 Wahhabism and Salafism are understood as inextricably linked phenomena (cf. Lohlker, Saudi Arabia).

13 A milieu we have called exclusivist in a former article (cf. Lohlker, Excluding the other). The tendencies mentioned are part of this common milieu trying to dominate Islamic societies.
} 
includes important theological and mystical aspects of Indonesian Islam, especially the centrality of compassion (rahma). ${ }^{14}$ We are not discussing all different aspects of the debate on figh in Indonesia. Neither the statements of political Islamic, Salafi/Wahhabi and Jihadi tendencies will be part of our analysis, nor will the local and provincial legislation be. We are following the process of "Indigenization of Islam" (pribumisasi Islam) mentioned above.

Thinking about Islam and figh in Southeast Asia does not mean giving a privilege to the study of normative, prescriptive Islam such as figh. We will have to take into account that the history of Islam in Southeast Asia was different from its history in Southwest Asia and North Africa as mentioned by Ahmed. Further, Peter Riddell says about the importance of Sufism in the early period of Southeast Asian Islam:

Scholars such as Hamzah Fansuri, Shams al-Din al-Sumatrani and 'Abd al-Ra'uf al-Singkili ensured that Sufi thought was to play a central role in defining the face of Islam in Southeast Asia. Indeed, in this way the Malay world has played a unique role in terms of the wider Muslim world. Whereas in the Middle East, Sufism had only emerged in a systematic way several centuries after the Islamisation process of the Arab world was complete, ${ }^{15}$ in the Malay world Sufism came to be normative during the formative years. As Bakar says, 'Sufism's greatest contribution to Malay civilization lies in shaping and crystallizing its intellectual and spiritual milieu during the later phase of the Islamisation process, from the ninth/fifteenth century until about the end of the twelfth/ eighteenth century.'16

Although we know about the importance of the literature of figh in early modern Southeast Asia until the 19th century, ${ }^{17}$ a thorough study of this literature still has to be carried out. We will have to restrict our exploration to some

\footnotetext{
14 This is not the place to delve into the ramifications of this idea.

15 Whether this picture of Islamization is accurate should be discussed, but there is no place to do it here. (RL)

16 Riddell, Islam and the Malay-Indonesian World, p. 168 et seq.

17 See Azra, The Origins of Islamic Reformism in Southeast Asia.
} 
general remarks. As Hooker wrote about the legacy of Islam (and Islamic law) in Southeast Asia putting the context we tried to describe above in other terms:

The key notion to keep in mind in assessing this legacy is the idea of selection. As with other Muslim lands outside the Arab heartland, the recipient cultures selected from the classical heritage that which they found useful or appropriate. This does not mean that the provincial cultures were, or are, less 'Muslim'. On the contrary, belief and identity as 'Muslim' are as strong in South-east Asia as in Arabia. It does, however, mean that the local cultural and language forms determined what Islam meant locally. In the broad sweep of Muslim history one can truly speak of 'Islams' just as one would speak of various forms of Christianity. The umma is one but the expression of the faith is culturally defined. There is no dispute about this as a fact, but there have always been movements from within Islam to minimise or do away with the cultural variations which have existed for centuries. ${ }^{18}$

The early modern law texts in Southeast Asia date back several centuries. This vast literature shows us the "purposeful selection"19 made during the process of indigenization of Islamic law in Southeast Asia. A good example of this process would be a Malayan ${ }^{20}$ law text,

Undang-Undang Melaka [...], which dates from the 17th century and was the most influential text for the succeeding two centuries. The text is short and has three parts, which respectively deal with debt and debt bondage, marriage and divorce and property rights. The first and the last represent local custom (adat) whilst marriage and divorce are recognisably derived from Islamic law. Perhaps most interesting is an interpolated section, which classifies the sources of law as (a) reason, (b) Islam and (c) customs of the country. A diversity of sources is recognised and, where there is conflict or inconsistency, then the Islamic element is ranked lower than the other two. The evidence from this text and other, later Malay-Muslim texts is that Islam was not the only source for law in the Muslim sultanates. While the genealogies of these sultanates lay great stress on relationships with the West Asian (that is, Middle Eastern) countries of Arab/ Islamic culture, this is not followed through in the law

20 Referring to the linguistic sphere and not to the contemporary political sphere. 
texts. Both, however, were produced at the same time and commissioned by the same ruler(s) and must, therefore, be read together. The result of this reading is to show that source and selection of Islamic principle is not haphazard or incompetent. On the contrary it shows a degree of originality in using Islamic principle for a purpose, namely to legitimise the ruler by reference to Islam. The religion here meant not just revelation but also attachment to the 'superior' West Asian civilisation. Some of the Malay-Muslim texts, in fact, include genealogies relating the texts' patrons to famous, ideal rulers of that area. While these might be fanciful in the historical sense, they were real for these who commissioned them. One might call these efforts 'myth' but, on another level, myths can also state truths. In our example, it is the illustration of the assimilation of foreign legal values. Of course the result is inconsistent but that is inevitable in any sort of cultural borrowing. ${ }^{21}$

Scholars of the 19th century imperial powers read this structure as a corruption of the 'real', 'pure' Islamic law, a dichotomy now convincingly criticized by Ahmed (see above) as ossifying Islam as a mere prescriptive system mirroring the views of parts of modern Islamic movements and taking these views as a genuine expression of Islam. Thus, this former state of research did not grasp the process of "exploration of meaning for the Self" described by Ahmed (see above) leading to the creation of the idea of Islam nusantara and humanitarian Islam in Indonesia.

One influential conceptualization for Indonesia was created by Christiaan Snouck Hurgronje when he formulated his famous systematic opposition distinguishing in all societal domains adat (custom) and hukum (Islamic law, figh). This opposition was criticized for many years; for our purposes we may state that this systematic opposition oversimplifies the situation in Aceh ${ }^{22}$ and ignores the process of purposeful selection and exploration (see above). ${ }^{23}$ Now, going back in time: By the end of the 18th century, the Islamic literature in general had expanded in Southeast Asia which still has to be studied in detail. There was a vast amount of literature trying to define sovereignty and rule.

In the earlier texts God's revealed message is subordinated to Islam used as a definition of sovereignty. The patrons of these earlier texts were

\footnotetext{
21 Hooker, Introduction: Islamic Law in South-East Asia, p. 216.

22 Snouck Hurgronje referred to Aceh, an Indonesian province, taking it as a case valid for all of Indonesia.

23 See Roff, Islam obscured?, p. 10 et seq.
} 
theologically illiterate but there is nothing new in this - present day politicians are, after all, usually constitutionally illiterate. By the end of the 18th century, however, a much greater degree of theological understanding can be shown; but, at the same time, the tension between the absoluteness of revelation and local cultural realities remained unresolved. ${ }^{24}$

During colonialism, especially Dutch colonialism for Indonesia, European legal imperialism was successful in reducing Islamic law to a personal religion and to the confines of personal status law bureaucratizing Islamic law in the form of Islamic courts that did not have a sizeable impact on figh. This system was transformed into the "Republic of Indonesia", reframing the Muslim legal discussion. ${ }^{25}$ This is not the place to discuss the history of Indonesian law in detail, but we can merely assume that it is justified to call the legal practice of Indonesia pluralistic. The "irreducible pluralism" of legal practice in Indonesia has been described by Bowen as:

Indonesian efforts to coexist through sustained public reasoning, a restless, endless process of deliberation, intended sometimes to accommodate others, sometimes to exclude them. I began in Isak, a small enough place, where if there were to be normative resting places in large nationstates, we might expect to find one. But Isak people, like their fellow citizens elsewhere, find themselves grappling with criss-crossing sets of norms, some of which have the backing of the state (and thus can be said to be 'law'), others of which have their normative anchors in the past or the local present. ${ }^{26}$

This irreducible legal pluralism combined with the specific Indonesian way of exploring the meaning of Islam leaves space for a theoretical, non-juridical discussion on figh. But: As Hooker asked in the introduction we quoted: "Is there no figh response to the challenge of modernity?"27 A case study of this kind of "figh response" may be the discussion on an Indonesian school of law $(\text { madhhab })^{28}$ based on thoughts about inheritance law:

\footnotetext{
24 Hooker, Introduction: Islamic Law in South-East Asia, p. 216.

25 For a general overview see Feener, Muslim Legal Thought in Modern Indonesia.

26 Bowen, Islam, Law and Equality in Indonesia, p. 253.

27 Hooker, Introduction: Islamic Law in South-East Asia, p. 230.

28 For a critique of the concept of "school" of law, see Lohlker, Die Richtungen des islamischen Rechts (madhāhib).
} 
The parallel between the earliest phase of growth of Islamic law and the present era lies in the fact that Islamic law is once again undergoing a process of intense borrowing and exchange similar to that which occurred at its creation. Doctrines and institutes whose provenance is outside of Islam are once again impinging on Islamic law. The future viability of Islamic jurisprudence depends in part on whether and how these new ingredients can be accommodated within the tradition. The question facing Islamic law is whether the achievements of the seventh and eighth centuries can be repeated in the twenty-first, and Islamic legal theory can once again assert its assimilating power to bring the ideals and institutions of modern society within an Islamic frame of reference.

The movement to create an Indonesian school of Islamic inheritance doctrine can be seen as part of renegotiating the terms of Islamic law to adapt the tradition to the conditions of modern life. The inheritance scheme advocated by the reformers is a self-consciously original construction intended as an Islamic inheritance law suited to the needs of contemporary Indonesian society. Unlike much contemporary Islamic legislation, which is based on ad hoc selection from recognized doctrines or manipulation of existing institutions, the Indonesian scheme of bilateral inheritance is unapologetically modern. Though progress toward the development of a modern Islamic legal theory has been more tentative, the outlines of an Indonesian Islamic jurisprudence are discernible, even if its details are not yet agreed upon. The basic premise of the approach are the belief in an Indonesian cultural exceptionalism, and Hazairin's insight that all interpretations of legal authorities are and should be shaped by historical and cultural conditioned interpretive categories. As yet, however, there is no convincing or agreed upon methodology for defining the limits of that principle or incorporating it within a coherent legal theory. ${ }^{29}$

Part of this discussion on a new inheritance law is, according to Cammack, ${ }^{30} \mathrm{a}$ double endeavor: to be accepted as Islamic and Indonesian. Thus, the rationale of this proposal is to create an Indonesian Islamic identity, an idea that goes quite well with the idea of Islam nusantara.

Speaking in terms of legal methodology and taking up the idea of new ijtihād, we will have to turn to some methodological or hermeneutical issues.

29 Cammack, Islam and Nationalism in Indonesia, p. 189.

30 See Cammack, Islam and Nationalism in Indonesia, p. 189 et seq. 
This aspect of the Indonesian discussion we have to look into is described by Kersten:

[...] fundamental intellectual debates on the role of religion in Muslim societies revolve around this central and yet illusively abstract notion of shari'a. Moreover, friend and foe are also in agreement that fiqh jurisprudence - was and actually still is the queen of sciences within traditional Islamic learning. When discussing the $\mathrm{NU}^{\prime} \mathrm{s}^{31}$ continuous reinterpretation of the meaning of Aswaja, ${ }^{32}$ I already touched on the fact that figh was identified as the best developed discipline in comparison with the two other parts of its intellectual triad: theology (kalam) and sufism (tasawwuf). Correspondingly, the rethinking of the NU's role following the decision to return to the Khittah 1926 is characterized as 'the total figh approach'. In this context, fiqh should not just be understood as referring to jurisprudence in a narrow legalistic sense. The opponents of the formal Islamization of Indonesia's legal system have a more expansive view of sharia. Instead of dealing with juridical technicalities - or debating the foundations underlying the practice of jurisprudence, a methodological sub-discipline known as usul al-figh - they advocate an even more fundamental philosophical discussion on the objectives underlying shari'a as a conceptualization of equity and justice. This further abstraction takes the whole matter of legal thought into the domains of philosophy, in particular hermeneutics and ethics. Since the classical era this has been dealt with by another sub-discipline within the tradition of Islamic learning, known as maqasid al-shari'a - the 'higher objectives of shari'a. ${ }^{33}$

Maqūsid al-sharīa $a{ }^{34}$ the higher objectives, are often referred to together with maslaha, the purpose of Islamic law. ${ }^{35}$ Both concepts are understood - to give a broad definition - as developing choice and preferences in an Islamic law perspective according to the higher interests of the Islamic community.

$31 \quad$ Nahdatul Ulama, the world's largest Muslim organization. (RL)

32 A central concept of the more recent discussions of NU. It is an abbreviation of Ahl asSunna wal-jamā'a and denotes a field of interpretation of how the idea of being a ,middle community' that is moderate is to be understood and which methodology (manhaj) is the outcome of this self-understanding. (RL)

33 Kersten, Islam in Indonesia, p. 179 et seq.

34 The vast literature on maqāsid cannot be discussed here.

35 See for a history of this concept Opwis, Mașlaha and the Purpose of Law. 


\section{$5 \quad$ Maqāsid al-Sharī'a and the Indonesian Debate}

An important methodical instrument for rethinking usūl al-figh in Indonesia ${ }^{36}$ today is this idea of the priority of the higher objectives of Islamic law, the maquasid al-sharīa, in the following text translated as "basic aims". ${ }^{37} \mathrm{~A}$ very succinct formulation of an Indonesian view on the maqasid is to be found in the introduction of the Gender Mainstreaming Team to a text called "Reforming Islamic Law" (Pembaruan Hukum Islam):

In the [new] formulation of sharia all citizens have the same status and access to justice; minorities and women are protected and guaranteed equal rights. The formulations are based on the basic aims of Sharia Islam (maqashid al-syari'at), that is, to establish values and principles of social justice, the welfare of the community of human beings, universal compassion and local wisdom. It has been prepared in Indonesian with current idioms, not Arabisms, and can be understood by Indonesians. ${ }^{38}$

Nevertheless, the maqāsid are from a restrictive point of view of fiqh not to be understood as a principle overruling every other ruling. Even trying to rethink figh according to new paradigms like "social fiq $h$ " will be restricted by what is understood as the "classical paradigm" and anxiety "to go too far or uproot figh from its orthodoxy tradition". ${ }^{39}$ M.A. Sahal Mahfudh ${ }^{40}$ concludes his article on social figh:

For this purpose, we need to make efforts of paradigmatic change within religious practical, that being figh. The paradigmatic change in viewing figh is a must. Fiqh cannot be seen just as a tool to measure the truth of orthodox religion, but must also be considered as a tool that can read social reality. In this case, figh has a dual function, firstly as a tool to measure social reality with shariah ideals, concluding with the decision of halal and haram laws, permitted or prohibited: and secondly at the same time it becomes a tool for social engineering. Within the science of law, there is always a dual function, the function of law as social control and as social engineering.

36 For an overview see Khoiri, The Mapping of Renewal of 'Usul Figh' Thoughts in Indonesia.

37 In Indonesian it is maqashid al-syari'at.

38 The translation in Fealy/Hooker, Voices of Islam in Southeast Asia, p. 148 et seq.

39 Fealy/Hooker, Voices of Islam in Southeast Asia, p. 161.

40 Former president of the Nahdlatul Ulama (NU), the largest Muslim organization worldwide. 
Both the functions of figh mentioned will only be made possible if the products and thinking of figh are developed contextually. Contextual figh approaches can be carried out, by putting the products of $f i g h$ within classical texts and academic life in their present and respective contexts. The products of figh can become models to develop madhhab qawli. The contextual figh approach can also work by expanding the madhhab perspective, through the application of usul al-figh and figh norms, as well as, through the integration of 'illat (reasoning) and the benefit (hikmah). ${ }^{41}$

We easily detect the key elements hampering any further development of the thinking about figh even in advanced approaches like that of social figh advocated here. The predominance of putting ideas within the framework of "classical texts" and the introduction of "shari'ah ideals" as a regulating idea for contextualizing figh is a key element. These elements easily allow for a reconfiguring of figh as an ossified element in Muslim societies even if the author advocates maquasid al-sharīa as an important tool for reform.

Even if we are leaving the many articles on maqāsid in Islamic Finance, Islamic Economy, bioethics, or medical ethics out, the number of articles devoted to discussions on maqāsid al-sharî́a demonstrates the importance of these discussions for the contemporary Indonesian on figh issues. ${ }^{42} \mathrm{~A}$ significant article on the Indonesian Pancasila constructs it as a contemporary application of maqāsid al-sharía ${ }^{43}$ Thus, the author demonstrates paradigmatically the indigenization of the methodology of Islamic law. This intense discussion in Indonesia allows, however, for a new flight line to emerge from the older debate moving to new stages of the application of usül al-figh and a redefinition of this methodology.

\section{Turning to the Idea of Humanitarian Islam}

The next stage of the unfolding of new lines of flight ${ }^{44}$ of the discussion on usūl al-figh in Indonesia is the emergence of the concept of a humanitarian Islam.

\footnotetext{
41 Fealy/Hooker, Voices of Islam in Southeast Asia, p. 16o; the transcription of Arabic words is not homogenized to one system.

E.g., Djamil, The Muhammadiyah and the Theory of Maqasid al-Shariah; Ubaidillah, Figh al-Būah; Sabil, Dinamika Teori Maqāṣid; Mudzhar, Revitalisasi Maqāṣid al-Sharīah; Shafei, Islamic Modernities in Southeast Asia.

43 See Acac, Pancasila.

44 We are referring to a well-known Deleuzian concept we cannot elaborate on here (see Lohlker, Islamische Texte).
} 
This concept was mentioned in the "Decree of the 21st National Conference of Gerakan Pemuda Ansor", the youth wing of the Nahdlatul Ulama (NU), in April 2017. The decree summons the organization to:

Assume a leadership role in a global movement to promote Humanitarian Islam (al-islam li al-insaniyyah), by developing and operationalizing a strategy to recontextualize (i.e., reform) the teachings of orthodox, authoritative Islam and thereby address certain problematic elements of figh, such as:

- Normative practices governing relations between Muslims and nonMuslims, including the rights, responsibilities and role of non-Muslims who live in Muslim-majority societies, and vice versa;

- Relations between the Muslim and non-Muslim world, including the proper aims and conduct of warfare;

- The existence of modern nation states and their validity - or lack thereof - as political systems that govern the lives of Muslims; and State constitutions and statutory laws/legal systems that emerged from modern political processes, and their relationship to shariah. ${ }^{45}$

Following this flight line, we reach May 22, 2017, an international gathering of nearly 300 Muslim scholars trying to devise a strategy helping to globalize the views developed in the process we sketched before. This gathering promulgated a declaration carrying the idea of a humanitarian Islam in its title.

The declaration carries the title Gerakan Pemuda Ansor Declaration on Humanitarian Islam: Towards the Recontextualization of Islamic Teachings, for the Sake of World Peace and Harmony Between Civilizations and is organized in 112 points. The last point summarizes the gist of this declaration:

From the perspective of usul figh (the theory of classical Islamic law), this will serve as the legitimate basis for new ijtihad that reflects the transformed reality of interfaith relations in the 21st century. The recontextualization of Islamic teachings will, in turn, support efforts to contain religious extremism, resolve conflict and transform educational curricula - thereby fulfilling the purpose of religious norms (maqasid 
al-shariah), which is to promote the spiritual and material well-being of humanity. ${ }^{46}$

The declaration by this article 112 focuses on the methodological issues enabling figh to be transformed and recontextualized in a way it will follow the basic "intentions of the Shariah" or "religious norms" (maqāsid al-sharīa). Thus, the declaration is leaving the confines of the idea of maqāsid mentioned above. The final article is building upon the ideas in the contextual points at the beginning of the document:

1. In the theory of classical Islamic law (usul fiqh), religious norms (akham; singular, $h u k m$ ) constitute a response to reality. The purpose of religious norms (maqasid al-shariah) is to ensure the spiritual and material wellbeing of humanity.

2. The authoritative Sunni jurists, Imam al-Ghazali and Imam al-Shatibi, identified five primary components of maqasid al-shariah, viz., the preservation of faith, life, progeny, reason and property.

3. Religious norms may be universal and unchanging - e.g., the imperative that one strive to attain moral and spiritual perfection - or they may be "contingent," if they address a specific issue that arises within the everchanging circumstances of time and place.

4. As reality changes, contingent - as opposed to universal - religious norms should also change to reflect the constantly shifting circumstances of life on earth. This was in fact the case during the early centuries of Islam, as various schools of Islamic law (madzhab) emerged and evolved. For the past five centuries, however, the practice of ijtihad (independent legal reasoning, employed to create new religious norms) has generally lapsed throughout the Sunni Muslim world.

5. When contemporary Muslims seek religious guidance, the most widelyaccepted and authoritative reference source - indeed, the standard of Islamic orthodoxy - is the corpus of classical Islamic thought (turats) and especially figh (jurisprudence) - that reached its peak of development in the Middle Ages and was then frozen in place, largely unchanged to the present day.

6. A wide discrepancy now exists between the structure of Islamic orthodoxy and the context of Muslims' actual (lived) reality, due to immense changes that have occurred since the teachings of orthodox Islam grew ossified towards the end of the medieval era.

46 Baytarrahmah, Gerakan Pemuda Ansor. 
7. This disjunct between key tenets of Islamic orthodoxy and the reality of contemporary civilization can, and often does, lead Muslims into physical, moral and spiritual danger, if they insist upon observing certain elements of figh, regardless of their present context. Among the complex issues that lie at the heart of this discrepancy are:

- Normative practices governing relations between Muslims and nonMuslims, including the rights, responsibilities and role of non-Muslims who live in Muslim-majority societies, and vice versa;

- Relations between the Muslim and non-Muslim world, including the proper aims and conduct of warfare;

- The existence of modern nation states and their validity - or lack thereof - as political systems that govern the lives of Muslims; and

- State constitutions and statutory laws/legal systems that emerged from modern political processes, and their relationship to shari'ah.

8. Social and political instability, civil war and terrorism all arise from the attempt, by ultraconservative Muslims, to implement certain elements of figh within a context that is no longer compatible with said classical norms.

9. Any attempt to establish a universal Islamic state - al-imamah al-udzma (the Great Imamate), also known as al-khilafah (the Caliphate) - will only lead to disaster for Muslims, as one aspirant battles with another for dominion of the entire Islamic world. ${ }^{47}$

The declaration constructs an interrelation of political, social and religious factors causing the need for a rethinking of figh following the idea of maqāsid interpreted in a non-restrictive manner, a specific Islam nusantara approach allowing for a flexible interpretation of figh that is based on an indigenized understanding, put in a globalized context and universalizing it.

The next milestone was the Nusantara Manifesto promulgated on October 25, 2019 by Gerakan Pemuda Ansor and the international NGo Bayt Ar Rahma in Yogyakarta. The point of this manifesto pertinent to mention in the context of our discussion is summarized as follows:

Part XI of the Manifesto (points 99-173) employs the science of uṣül alfigh - the methodology of independent legal reasoning used to create Islamic law, or figh - to examine why it is theologically valid and necessary for contemporary Muslim scholars to recontextualize obsolete and problematic tenets within Islamic orthodoxy, which are used to justify religious hatred, supremacy and violence. Section $\$ 11.2$ explains why 
changed circumstances necessitate new ijtihäd to ensure the well-being of humanity (maqāssid al-sharīah). Section §11.3 incorporates H.E. Kyai Haji Abdurrahman Wahid's historic essay, "God Needs No Defense," while section $§ 11.5$ establishes a framework for the emergence of what the Nusantara Manifesto calls figh al-hadārah al-ālamìyah al-mutașahirah (Islamic jurisprudence for a single, interfused global civilization). ${ }^{48}$

The manifesto incorporates some of the points mentioned in the declaration on humanitarian Islam in a more detailed way. The Nusantara Manifesto was discussed at a meeting of seventy Islamic scholars at a prominent Islamic boarding school and was co-sponsored by the Gerakan Pemuda Ansor and its theological wing Rijalul Ansor. The meeting was held on January 3, 2019, and discussed the necessities arising from the manifesto. One of the participants K.H. Abu Yazid Bustami, Deputy General Secretary of Rijalul Ansor, stated: "The only solution to the crisis facing Muslim communities worldwide is to construct a global figh that reflects our present reality. We [Nahdlatul Ulama theologians] have the requisite ability, courage and authority to conduct ijtihad!!!"49

This may be understood as opening a new stage of developing a new figh, not only adapting to the circumstances of modernity but reclaiming the competence for a new ijtihād from movements emerging in the Middle East since the 19th century. The last result of this ongoing process is a short statement called Nusantara Statement promulgated by Ansor at a mass rally on November 22, 2018 , on the occasion of the birthday of the prophet (mawlid) ${ }^{50}$ and attended by the Indonesian president Joko Widodo. The statement reads:

We call upon people of goodwill of every faith and nation to join in building a global consensus to prevent the political weaponization of Islam, whether by Muslims or non-Muslims, and to curtail the spread of communal hatred by fostering the emergence of a truly just and harmonious world order, founded upon respect for the equal rights and dignity of every human being. ${ }^{51}$

48 Baytarrahmah, Gerakan Pemuda Ansor.

49 Baytarrahmah, Islamic jurisprudence for a global civilization.

50 See Kaptein, Muhammad's Birthday Festival; Katz, The Birth of the Prophet Muhammad; Kaptein, The Berdiri Mawlid Issue; Woodward, The Garebeg Malud.

51 Baytarrahmah, Blocking the political weaponization of Islam. 
Thus, we witness a seemingly technical debate on the methodology of figh in Indonesia turning into a religio-political statement with a potentially global impact. We may understand this statement as the final proof of indigenization cum globalization cum universalization of $f$ igh in Indonesia.

Hence, it is possible to understand this process of indigenization as the development of a genuine Indonesian school of thought ${ }^{52}$ beginning to operate at a global level and claiming Islam as part of the universal values of humanity and not excluding other Islamic and non-Islamic parts of the global society.

\section{Biography}

Rüdiger Lohlker is a professor of Islamic Studies at the Oriental Institute at the University of Vienna. One of his research topics is Islam in Indonesia. He furthermore researches phenomena like Jihadism, Salafism, Medical Humanities, Science Studies and Islam and the Internet.

\section{Bibliography}

Acac, Marybeth T.: Pancasila: A Contemporary Application of Maqāṣid al-Sharīah?, in: Journal of Indonesian Islam gi (2015), pp. 59-78.

Ahmed, Shahab: What is Islam? The Importance of being Islamic. Princeton, NJ: Princeton University Press 2016.

Arifianto, Alexander R.: Islam Nusantara: NU's Bid to Promote 'Moderate Indonesian Islam'. Singapore: RSIS 2016.

Azra, Azyumardi: The Origins of Islamic Reformism in Southeast Asia: Networks of Malay-Indonesian and Middle Eastern 'ulamā' in the seventeenth and eighteenth centuries. Crows Nest, NSW: Allen and Unwin 2004.

Azra, Azyumardi: Islam Nusantara: Jaringan global dan lokal. Bandung, Mizan: Didistribusikan oleh Mizan Media Utama 2002.

Bisri, A. Musafa/Taylor, C. Holland: Indonesia's 'Big Idea': Resolving the Bitter Global Debate on Islam, in: Strategic Review ziii (2012), pp. 34-41.

Bowen, John R.: Islam, Law and Equality in Indonesia: An Anthropology of Public Reasoning. Cambridge: Cambridge University Press 2003.

$5^{2}$ Against possible misunderstandings we have to stress that we are not talking about an Indonesian madhhab. 
Cammack, Mark E.: Islam and Nationalism in Indonesia: Forging an Indonesian Madhhab, in: Berman, Peri et al. (eds.): The Islamic School of Law: Evolution, Devolution, and Progress. Cambridge, MA: Harvard University Press 2015, pp. 174-19o. Djamil, Fathurrahman: The Muhammadiyah and the Theory of Maqasid al-Shariah, in: Studia Islamika 2i (1995), pp. 53-68.

Fealy, Gregg/Hooker, Virginina (eds.): Voices of Islam in Southeast Asia: A Contemporary Sourcebook. Singapore: ISEAS 2006.

Feener, R. Michael: Muslim Legal Thought in Modern Indonesia. Cambridge: Cambridge University Press 2007.

Hallaq, Wael B.: A History of Islamic Legal Theory: An Introduction to Sunnī uṣūl al-fiqh. Cambridge: Cambridge University Press 1997.

Hasyim, Syafiq: 'Islam Nusantara' and its Discontents. Singapore: RS IS 2018.

Hooker, M.B.: Introduction: Islamic Law in South-East Asia, in: Australian Journal of Asian Law 4iii (2002), pp. 213-231.

Kaptein, Nico J.G.: Muhammad's Birthday Festival: Early History in the Central Muslim Lands in the Muslim West until the 1oth/16th Century. Leiden et al.: Brill 1993a.

Kaptein, Nico J.G.: The Berdiri Mawlid Issue among Indonesian muslims in the period from circa 1875 to 1930, in: Bijdragen tot de Taal-, Land- en Volkenkunde 149 i (1993b), pp. 124-153.

Katz, Marion Holmes: The Birth of the Prophet Muhammad: Devotional Piety in Sunni Islam. London/New York: Routledge 2007.

Kersten, Carool: Islam in Indonesia: The Contest for Society, Ideas and Values. London: Hurst \& Co. Publishers and Oxford University Press 2015.

Khabibi, Muhammad Lutfi: Islam Nusantara: Relasi Islam dan Budaya Lokal, in: Shahih ii (2016), pp. 1-12.

Khoiri, Nispul: The Mapping of Renewal of ,Usul Fiqh' Thoughts in Indonesia, in: International Journal on Language, Research and Education Studies $i$ (2017), pp. $18-33$.

Lohlker, Rüdiger: Saudi Arabia in the Mirror of Saudi Cables, Berlin: Logos 2020.

Lohlker, Rüdiger: Variantologie des Universellen: Potentiale der islamischen Traditionen für Toleranz, Dialog und Pluralismus, in:Irmtraut Fischer et al.(eds.): Hat derjüdischchristliche Dialog Zukunft? Gegenwärtige Aspekte und zukünftige Perspektiven in Mitteleuropa. Göttingen: Vandenhoeck \& Ruprecht 2017, pp. 197-205.

Lohlker, Rüdiger: Excluding the Other: Wahhabism, Salafism, Jihadism, and Political Islam, in: Totalitarismus und Demokratie 14ii (2017), pp. 265-289.

Lohlker, Rüdiger: Die Richtungen des islamischen Rechts (madāhib): Überlegungen zur Geschichte und Struktur, in: Jameleddine Ben Abdeljelil (ed.): Historizität und Transzendenz im Islam: Offenbarung, Geschichte und Recht. Berlin: 2017, pp. 229-240. Lohlker, Rüdiger: Islamisches Recht. Wien: UTB, Facultas 2016. 
Lohlker, Rüdiger: Islamische Texte - Bewegungen der Deterritorialisierung und Umordnung der Dinge, in: Kurt Appel et al. (eds.): Religion in Europa heute: Sozialwissenschaftliche, rechtswissenschaftliche, hermeneutisch-religionsphilosophische Perspektiven. Göttingen: Vandenhoeck \& Ruprecht 2012, pp. 193-208.

Mudzhar, M. Atho: Revitalisasi Maqāṣid al-Sharīah dalam Pengembangan Ekonomi Syariahdi Indonesia (Studi Kasus atas Fatwa-fatwa DSN-MUI Tahun 200o-2006), in: Indo-Islamika 4 i (2014), pp. 1-19.

Opwis, Felicitas: Maṣlaha and the Purpose of Law: Islamic Discourse on Legal Change from the 4th/1oth to 8th/14th Century. Leiden/Boston: Brill Academic 2010.

Qomar, Mujamil: Islam Nusantara: Sebuah Alternatif Model Pemikiran, Pemahaman, dan Pengamalan Islam, in: el Harakah r7ii (2015), pp. 198-215.

Quinn, George: Bandit Saints of Java: How Java's Eccentric Saints are challenging Fundamentalist Islam in Modern Indonesia. Burrough on the Hill, UK: Monsoon Books 2019.

Riddell, Peter: Islam and the Malay-Indonesian World: Transmission and Responses. Honolulu: University of Hawaii Press 2001.

Roff, William R.: Islam obscured? Some Reflections on Studies of Islam \& Society in Southeast Asia, in: L'Islam en Indonésie, Archipel 29 (I/1985), pp. 7-34.

Rumadi: Islamic Post-Traditionalism in Indonesia. Singapore: ISEAS 2015.

Sabil, Jabbar: Dinamika Teori Maqāșid, in: Jurnal Ilmiah Islam Futura 1oii (2011), pp. 36-49.

Schmidt, Leonie: Islamic Modernities in Southeast Asia: Exploring Indonesian Popular and Visual Culture. London: Rowman \& Littlefield 2017.

Shafei, Zakaria: Tracing Maqāṣid al-Sharỉah in the Fatwas of Indonesian Council of Ulama, in: Journal of Indonesian Islam ni (2017), pp. 99-124.

Susanto, Edy/Karimullah, Karimullah: Islam Nusantara: Islam Khas dan Akomodasiterhadap Budaya Lokal, in: Al-Ulum $16 i$ (2016), pp. 56-8o.

Ubaidillah, M. Hassan: Fiqh al-Bīah: Formulasi Konsep al-Maqāṣid al-Sharī’ah dalam Konservasi dan Restorasi Lingkungan, in: Al-Qānūn ızi (2010), pp. 26-52.

Wahid, Abdurrahman: Islam Kosmopolitan. Nilai-Nilai Indonesiaan dan Transformasi Kebudayaan. Jakarta: Wahid Institute 2007.

Woodward, Mark: The Garebeg Malud: Veneration of the Prophetas Imperial Ritual, in: Java, Indonesia and Islam. Dordrecht 2011, pp. 169-198.

\section{Internet Sources}

Baytarrahmah: Ansor Decree 2017. http://www.baytarrahmah.org/media/2017/Ansor -Decree_No.04_KONBESXXI_IV_2017.pdf (date of last access: 27.01.2019).

Baytarrahmah: Gerakan Pemuda Ansor 2017. http://www.baytarrahmah.org/media/ 2017/Gerakan-Pemuda-Ansor_Declaration-on-HumanitarianIslam.pdf (date of last access: 27.01.2019). 
Baytarrahmah: Islamic Jurisprudence 2019. http://baytarrahmah.org/2019_o1_o3_islamic -jurisprudence-for-a-global-civilization/ (date of last access: 27.01.2019).

Baytarrahmah: Blocking the weaponization of Islam 2018. http://baytarrahmah.org/ 2018_11_22_blocking-the-political-weaponization-of-islam/ (date of last access: 27.01.2019).

Wahid, Abdurrahman: Pribumisasi Islam. http://www.nu.or.id/post/read/6og85/pribu misasi-islam (date of last access: 27.02.2019). 